\title{
KUALITAS ANGKA KUMAN UDARA PADA RUANG PERSALINAN PRAKTIK BIDAN SWASTA DI KOTA BANJARBARU
}

\author{
Munawar Raharja \\ Poltekkes Kemenkes Banjarmasin Jurusan Kesehatan Lingkungan \\ e-mail: m_raharja@yahoo.com
}

\begin{abstract}
Microbial air count quality in the delivery room of midwife private practices in Banjarbaru City. The increasing role of private health care in the community, including midwife in private practice. The absence of rules on the environmental health of the midwife private practice led to a lack of sanitary supervision in the delivery room. A large number of microbial air in the delivery room can cause infection directly or indirectly through contaminated equipment used in the delivery process. To assess the microbial air count quality, state of health of the delivery room environment and determine the relationship between the quality of physical environment, physical building, and sanitation delivery room with microbial air count quality in the delivery room of midwife private practices in Banjarbaru City. This research used cross sectional survey design. The subject were all over the delivery rooms practices in Banjarbaru City midwife private with the inclusion criteria was still active, had a license, a separate private practice with a family room and were willing to participate in the study, namely 34 the delivery rooms. Data analysis was performed with the statistical analysis of univariate, bivariate with chi-square test and multivariate logistic regression analysis and descriptive data was analyzed by comparing the theoretical and applicable standards. A total of $29.4 \%$ the delivery rooms with the microbial air quality and $70.6 \%$ delivery rooms does not qualify. There were three variables associated with the study of microbial air quality, namely : the arrangement of the rooms, air circulation, and sanitary rooms. There is a significant relationship among the arrangement of the room, sanitary room, and air circulation to the microbial air quality in the delivery room, and the delivery room air circulation is a variable that contributes most greatly to the microbial air count quality in the delivery room midwife private practices in Banjarbaru City
\end{abstract}

Key words : air microbial, environmental health, delivery room, midwife

\begin{abstract}
Abstrak : Kualitas angka kuman udara pada ruang persalinan praktik bidan swasta di Kota Banjarbaru. Fakta menunjukkan telah terjadi peningkatan peran pelayanan kesehatan swasta bagi masyarakat, di antaranya praktik bidan swasta. Belum adanya aturan tentang kesehatan lingkungan pada praktik bidan swasta menyebabkan kurangnya pengawasan sanitasi pada ruang persalinan. Tingginya angka kuman udara pada ruang persalinan dapat menyebabkan infeksi secara langsung maupun tidak langsung melalui kontaminasi peralatan yang digunakan pada proses persalinan. Penelitian bertujuan mengetahui hubungan antara kualitas fisik lingkungan, fisik bangunan, dan sanitasi ruang persalinan dengan kualitas angka kuman udara pada ruang persalinan praktik bidan swasta di Kota Banjarbaru. Jenis penelitian yang digunakan survei dengan rancangan Cross sectional. Objek penelitian adalah 34 ruang persalinan pada praktik bidan swasta di Kota Banjarbaru dengan kriteri inklusi : masih aktif, memiliki izin praktik, tempat praktik terpisah dari ruangan keluarga dan bersedia berpartisipasi dalam penelitian. Analisis data dilakukan dengan uji statistik univariat, bivariat dengan uji chi-square dan analisis multivariat dengan regresi logistik pada $\alpha=0,05$. Sebanyak 29,4\% ruang persalinan dengan kualitas angka kuman udara memenuhi syarat dan 70,6\% ruang pesalinan tidak memenuhi syarat. Ada 3 variabel penelitian yang berhubungan dengan kualitas angka kuman udara, yaitu : penataan ruangan $(p=0,031)$, $\operatorname{sirkulasi}$ udara $(p=0,000)$, dan sanitasi ruangan $(p=0,010)$. Terdapat hubungan yang signifikan antara penataan ruangan, sirkulasi udara, dan sanitasi ruangan dengan kualitas angka kuman udara pada
\end{abstract}


ruang persalinan. Sirkulasi udara yang tidak memenuhi syarat merupakan variabel yang paling berpengaruh secara signifikan dan memberikan kontribusi paling besar terhadap kualitas angka kuman udara tidak memenuhi syarat pada ruang persalinan praktik bidan swasta di Kota Banjarbaru dengan nilai risiko relatif 45 kali.

Kata Kunci : kuman udara, kesehatan lingkungan, persalinan, bidan

\section{PENDAHULUAN}

Praktik bidan swasta merupakan penyedia layanan kesehatan, yang memiliki kontribusi cukup besar dalam memberikan pelayanan, khususnya dalam meningkatkan kesejahteraan ibu dan anak. Belum adanya regulasi yang mengatur pengawasan dalam penyelenggaraan pelayanan kesehatan swasta, terutama pada aspek kesehatan lingkungan, dapat menyebabkan perhatian terhadap sanitasi ruang persalinan belum optimum dilakukan oleh praktik bidan swasta, hal ini tentunya akan berpengaruh terhadap mutu layanan yang diberikan.

Faktor lingkungan merupakan salah satu faktor penting dalam terjadinya infeksi. Salah satu infeksi yang dikenal adalah infeksi karena kondisi lingkungan (Environmental infection) yang disebabkan oleh mikroorganisme yang terdapat pada benda atau bahan yang berada di lingkungan, sehingga dapat menyebabkan infeksi. Udara merupakan salah satu media pembawa bagi penyebaran mikroorganisme di lingkungan (1).

Infeksi nosokomial adalah infeksi yang diperoleh pasien selama berada di rumah sakit atau fasilitas sejenis. Kuman dapat ditularkan kepada pasien oleh petugas, pengunjung, tindakan dan lingkungan yang berada di sekitar pasien. Pengendalian Infeksi nosokomial terutama diarahkan untuk melindungi pasien, mengingat pasien yang dirawat umumnya lebih rentan atau lemah secara fisik maupun psikis akibat penyakit yang dideritanya (2).

Infeksi persalinan diantaranya dapat terjadi karena faktor lingkungan di sekitar tempat atau ruang persalinan seperti keadaan sanitasi lingkungan yang kurang baik, sehingga kualitas udara ruang persalinan akan menurun. Untuk itu perlu adanya upaya perbaikan kesehatan lingkungan praktik bidan swasta di antaranya kebersihan lingkungan khususnya udara. Selain itu ruang persalinan termasuk kategotri daerah rawan (high risk area) karena pasien yang menempati ruangan ini tergolong rentan terhadap infeksi (3).

Tujuan penelitian untuk menilai kualitas angka kuman udara dan mengetahui hubungan antara kondisi kualitas fisik lingkungan (suhu dan kelembaban udara), kondisi fisik bangunan (konstruksi bangunan, penataan ruangan, sirkulasi udara, dan adanya sinar matahari pagi yang dapat masuk seacara langsung ke ruang persalinan) dan kondisi sanitasi ruang persalinan dengan kualitas angka kuman udara pada ruang persalinan praktik bidan swasta di Kota Banjarbaru.

\section{BAHAN DAN CARA PENELITIAN}

Jenis penelitian yang digunakan adalah survei dengan rancangan studi potong lintang (Cross sectional). Subyek penelitian adalah seluruh ruang persalinan praktik bidan swasta di Kota Banjarbaru dengan kriteria inklusi; masih aktif, memiliki izin praktik, tempat praktik terpisah dengan ruangan keluarga dan bersedia berpartisipasi dalam penelitian, sehingga didapatkan subyek penelitian 34 ruang persalinan. Responden dalam penelitian ini adalah bidan yang bertanggungjawab pada praktik bidan swasta yang menjadi subyek penelitian.

Variabel yang diteliti adalah variabel bebas ( meliputi : kualitas suhu dan kelembaban udara, kontruksi bangunan, penataan ruangan, adanya sinar matahari pagi yang dapat secara langsung masuk ke dalam ruang persalinan, sanitasi ruang persalinan, dan sirkulasi udara) dan variabel terikat adalah kualitas angka kuman udara pada ruang persalinan praktik bidan swasta. 
Analisis data dilakukan dengan analisis statistik univariat, bivariat dengan uji Chisquare dan analisis multivariat berupa regresi logistik, dengan taraf kepercayaan 95\%.

Pengukuran parameter lapangan, observasi kondisi ruang persalinan dan pengambilan sampel udara dilakukan di tempat penelitian dan dilanjutkan dengan pemeriksaan di laboratorium untuk mengetahui indeks angka kuman udara (4).

HASIL DAN PEMBAHASAN

Tabel 1 Distribusi Frekuensi Objek Penelitian Menurut Kualitas Angka Kuman Udara

\begin{tabular}{cccc}
\hline \multirow{2}{*}{ Variabel } & Kategori & Frekuensi (f) & Persentase (\%) \\
\hline Kualitas angka kuman Udara & $\bullet$ Tidak Memenuhi Syarat & 24 & 70,6 \\
& $\bullet$ Memenuhi Syarat & 10 & 29,4 \\
\hline & Jumlah & 34 & 100 \\
\hline
\end{tabular}

Hasil pengamatan variabel bebas terhadap variabel terikat angka kuman udara pada objek penelitian dapat dilihat pada Tabel

2 dan Tabel 3 memperlihatkan hasil uji statistik antara variabel bebas dengan variabel terikat.

Tabel 2 Tabulasi Silang Variabel Bebas dengan Variabel Terikat

\begin{tabular}{|c|c|c|c|c|c|c|c|}
\hline \multirow{3}{*}{ Variabel } & \multirow{3}{*}{ Kategori } & \multicolumn{6}{|c|}{ Kualitas angka kuman Udara } \\
\hline & & \multicolumn{2}{|c|}{ TMS } & \multicolumn{2}{|c|}{ MS } & \multirow[t]{2}{*}{ Total } & \multirow[t]{2}{*}{$\%$} \\
\hline & & ${ }^{\circ} \mathrm{C}$ & $\%$ & ${ }^{\circ} \mathrm{C}$ & $\%$ & & \\
\hline Suhu Udara & Tidak Sesuai Standar & 24 & 70,6 & 10 & 29,4 & 34 & 100 \\
\hline Kelembaban Udara & Tidak Sesuai Standar & 24 & 70,6 & 10 & 29,4 & 34 & 100 \\
\hline \multirow[t]{2}{*}{ Konstruksi Ruangan } & Tidak Memenuhi Syarat & 8 & 100 & 0 & 0 & 8 & 100 \\
\hline & Memenuhi Syarat & 16 & 61,5 & 10 & 38,5 & 26 & 100 \\
\hline \multirow[t]{2}{*}{ Penataan Ruangan } & Tidak Baik & 21 & 80,8 & 5 & 19,2 & 26 & 100 \\
\hline & Baik & 3 & 37,5 & 5 & 62,5 & 8 & 100 \\
\hline \multirow[t]{2}{*}{ Sinar matahari pagi } & Tidak Ada & 24 & 75 & 8 & 25 & 32 & 100 \\
\hline & Ada & 0 & 0 & 2 & 100 & 2 & 100 \\
\hline \multirow[t]{2}{*}{ Sanitasi ruangan } & Tidak Baik & 17 & 89,5 & 2 & 10,5 & 19 & 100 \\
\hline & Baik & 7 & 46,7 & 8 & 53,3 & 15 & 100 \\
\hline \multirow[t]{2}{*}{ Sirkulasi Udara } & Tidak Memenuhi Syarat & 20 & 95,2 & 1 & 4,8 & 21 & 100 \\
\hline & Memenuhi Syarat & 4 & 30,8 & 9 & 69,2 & 13 & 100 \\
\hline $\begin{array}{ll}\text { TMS } & = \\
\text { MS } & =\end{array}$ & $\begin{array}{l}\text { Tidak Memenuhi Syarat } \\
\text { Memenuhi Syarat }\end{array}$ & & & & & & \\
\hline
\end{tabular}


Tabel 3 Hasil Analisis Hubungan Antara Variabel Bebas dan Variabel Terikat

\begin{tabular}{|c|c|c|c|}
\hline \multirow[b]{2}{*}{ Variabel } & \multicolumn{3}{|c|}{ Kualitas Angka Kuman Udara pada Ruang Persalinan } \\
\hline & Chi Square $\left(\chi^{2}\right)$ & $\begin{array}{c}\text { Sig, (p) Fisher's Exact } \\
\text { Test }\end{array}$ & $\begin{array}{l}\text { Contingency } \\
\text { Coefficient }\end{array}$ \\
\hline Konstruksi Bangunan & 4,359 & 0,072 & 0,337 \\
\hline Penataan Ruangan & 5,517 & 0,031 & 0,374 \\
\hline Sinar matahari Pagi & 5,100 & 0,080 & 0,361 \\
\hline Sanitasi Ruangan & 7,398 & 0,010 & 0,423 \\
\hline Sirkulasi Udara & 16,074 & 0,000 & 0,567 \\
\hline
\end{tabular}

Berdasarkan tabel tabulasi silang (Tabel 2), kualitas suhu udara dan kualitas kelembaban udara tidak dapat dilanjutkan pada analisis bivarat (uji Chi Square), karena hanya ada satu baris data yang dapat dimasukkan dalam analisis tabulasi silang (Crosstabulation), sehingga analisis bivariat (uji Chi-square) hanya dilakukan pada variabel bebas konstruksi bangunan, penataan ruangan, sirkulasi udara, sinar matahari pagi, dan sanitasi ruangan (Tabel 3).

Berdasarkan hasil pemeriksaan, suhu udara pada ruang persalinan berkisar antara 26,3 - $32^{\circ} \mathrm{C}$. Sedangkan kelembaban udara berkisar antara 69,0 - 87,2\%RH, dari hasil ini tidak ada suhu dan kelebaban udara pada ruang persalinan yang memenuhi standar menurut Kepmenkes RI No. 1204/Menkes/SK/X/2004, yaitu untuk kualitas suhu udara ruang persalinan adalah 24 - $26^{\circ} \mathrm{C}$ dan kelembaban udara 45 $60 \%$ RH. Kondisi ini merupakan suhu dan kelembaban optimum bagi pertumbuhan bakteri golongan mesophilik dan beberapa jamur saprophyt. Walaupun demikian mikroorganisme di udara kemungkinan tidak akan berkembang biak, karena tidak tersedianya nutrisi yang diperlukan untuk proses pembelahan sel mikroba tersebut.

Hasil penelitian ini menunjukkan semua ruang persalinan dengan konstruksi bangunan yang tidak memenuhi syarat menunjukkan kualitas angka kuman udara yang tidak memenuhi syarat. Akan tetapi sebagian besar ruang persalinan dengan kondisi konstruksi bangunan yang memenuhi syarat juga menunjukkan kualitas angka kuman udara yang tidak memenuhi syarat $(61,5 \%)$, sehingga pada analisis bivariat dengan uji Chi-square menunjukkan bahwa tidak terdapat hubungan yang signifikan antara kondisi kontruksi bangunan dengan kualitas angka kuman udara.

Hasil penelitian ini menunjukkan bahwa sebagian besar ruang persalinan dengan penataan yang tidak baik juga menunjukkan kualitas angka kuman ruang tersebut tidak memenuhi syarat $(80,8 \%)$ dan sebagaian besar ruang persalinan dengan penataan yang baik juga akan menunjukkan kualitas angka kuman udara yang memenuhi syarat $(62,5 \%)$.

Analisis bivariat dengan uji Chi-square juga membuktikan bahwa terdapat hubungan yang signifikan antara penataan ruangan dengan kualitas angka kuman udara $p$ value $=$ $0,031(p<0,05)$, hal ini dapat dikarenakan kondisi penataan ruangan yang tidak baik, berupa tidak adanya pemisahan ruang persalinan dengan ruang periksa dapat berpengaruh terhadap kondisi sanitasi ruangan, karena aktivitas pasien yang banyak pada saat pemeriksaan dapat menyebabkan ruangan mudah kotor, dan mikroba juga dapat berasal dari aktivitas manusia (6). Adanya benda-benda yang bukan untuk pertolongan persalinan pada ruang persalinan juga dapat menyulitkan tindakan pembersihan ruang persalinan.

Hasil peneltian menunjukkan bahwa sebagian besar ruang persalinan yang tidak dapat dimasuki sinar matahari pagi secara 
langsung, menunjukkan kualitas angka kuman yang tidak memenuhi syarat (75\%), dan 2 ruang persalinan dengan adanya sinar matahari pagi yang dapat secara langsung masuk ke dalam ruangan menunjukkan kualitas angka kuman yang memenuhi syarat, Akan tetapi karena hanya ada 2 ruang persalinan dengan adanya sinar matahari pagi yang digunakan sebagai data dalam analisis statistik, maka pada saat uji statistik hubungan sinar matahari pagi yang dapat secara langsung masuk ke dalam ruang persalinan dengan kualitas angka kuman udara tidak menunjukkan hubungan yang signifikan.

Jendela yang dapat dibuka atau jendela kaca dengan posisi yang tepat dapat memasukkan sinar matahari pagi kedalam ruang persalinan, sehingga jendela selain sebagai ventilasi alami juga dapat sebagai sumber penerangan ruangan. Ruang persalinan dengan cukup sinar matahari pagi yang dapat masuk, amat baik untuk ruangan, karena matahari pagi antara jam 08.00 10.00 mengandung sinar ultraviolet yang dapat membunuh mikroorganisme (7).

Dari hasil observasi terhadap sanitasi ruang persalinan praktik bidan swasta di Kota Banjarbaru, terdapat 19 ruang persalinan dengan kondisi sanitasi yang tidak baik $(55,9 \%)$ dan 15 ruang persalinan dengan kondisi sanitasi yang baik $(44,5 \%)$. Berdasarkan hasil wawancara terhadap responden, yaitu bidan yang bertanggung jawab pada lokasi penelitian tentang kegiatan sanitasi yang dilakukan pada ruang persalinan, didapatkan informasi bahwa : Sebagian besar responden sudah melakukan pembersihan ruang persalinan, akan tetapi pembersihan yang dilakukan masih belum optimal, karena pada saat observasi dilakukan masih banyak terdapat ruang persalinan dengan kondisi sanitasi yang tidak baik. Disamping itu terdapat 10 responden yang menyatakan melakukan pembersihan dinding dan langit-langit ruang persalinan secara rutin satu atau dua minggu sekali $(29,4 \%)$.

Hasil penelitian menunjukkan sebagian besar ruang persalinan dengan kondisi sanitasi yang tidak baik menunjukkan kualitas angka kuman udara yang tidak memenuhi syarat $(89,5 \%)$. Sedangkan pada ruang persalinan dengan kondisi sanitasi yang baik terdapat 53,5\% ruangan dengan kondisi kualitas angka kuman udara memenuhi syarat dan 46,7\% tidak memenuhi syarat.

Hasil analisis bivariat dengan uji Chisquare membuktikan bahwa terdapat hubungan yang signifikan antara sanitasi ruang persalinan dengan kualitas angka kuman udara, $p$ value $=0,010(p<0,05)$. Hal ini dapat dikarenakan kondisi sanitasi yang tidak baik, seperti sanitasi langit-langit, dinding, dan lantai yang kotor dan berdebu dan kemungkinan mengandung mikroorganisme akan berpengaruh terhadap kualitas angka kuman udara bila ada hembusan angin yang membawanya ke udara, Apabila hembusan angin atau aliran udara yang terjadi sangat lambat kemungkinan mikroba tersebut akan lebih lama berada di dalam ruangan tersebut, karena akan terapung-apung di udara.

Dari hasil observasi pada saat penelitian terdapat 28 ruang persalinan menggunakan ventilasi alami, dan 7 ruang persalinan memiliki luas ventilasi alami memenuhi persyaratan, yaitu lebih dari 15\% dari luas lantai. Terdapat 5 ruang persalinan memiliki ventilasi gabungan yaitu terdapat AC dengan jendela yang dapat dibuka sehingga juga berfungsi sebagai ventilasi udara, dengan luas jendela lebih dari 5\% dari luas lantai, serta terdapat 1 ruang persalinan menggunakan AC tanpa ada lubang ventilasi dan jendela yang dapat dibuka.

Hasil penelitian ini menunjukkan sebagian besar ruang persalinan dengan sirkulasi udara tidak memenuhi syarat menunjukkan hasil kualitas angka kuman udara tidak memenuhi syarat $(95,2 \%)$, dan sebagaian besar ruang persalinan dengan ventilasi yang memenuhi syarat menunjukkan kualitas angka kuman udara yang memenuhi syarat $(62,5 \%)$.

Analisis bivariat dengan uji Chi-square juga membuktikan bahwa terdapat hubungan yang signifikan antara sirkulasi udara ruangan dengan kualitas angka kuman udara, $p$ value $=0,000(p<0,05)$. 
Tabel 4 Hasil Analisis Regresi Logistik Antara Variabel Bebas yang Diprediksi Memiliki Hubungan dengan Kualitas Angka Kuman Udara pada Ruang Persalinan Bidan Praktik di Kota Banjarbaru

\begin{tabular}{rlrrr}
\hline \multirow{2}{*}{ Model } & \multicolumn{1}{c}{ Variabel Bebas } & Wald & Sig. & \multicolumn{1}{c}{ Exp(B) } \\
\hline \multirow{2}{*}{1} & Konstruksi Bangunan & 0,000 & 0,999 & $3,337.10^{-7}$ \\
\cline { 2 - 5 } & Penataan Ruangan & 0,001 & 0,977 & 1,043 \\
\cline { 2 - 5 } & Sinar Matahari Pagi & 0,000 & 0,999 & $1,966.10^{-9}$ \\
\cline { 2 - 5 } & Sanitasi Ruangan & 1,785 & 0,182 & 8,031 \\
\cline { 2 - 5 } & Sirkulasi Udara & 4,490 & 0,034 & 19,419 \\
\hline \multirow{2}{*}{2} & Konstruksi Bangunan & 0,000 & 0,999 & $5,581.10^{-7}$ \\
\cline { 2 - 5 } & Penataan Ruangan & 0,267 & 0,605 & 1,893 \\
\cline { 2 - 5 } & Sanitasi Ruangan & 1,457 & 0,227 & 4,245 \\
\cline { 2 - 5 } & Sirkulasi Udara & 5,698 & 0,017 & 21,955 \\
\hline \multirow{2}{*}{3} & Penataan Ruangan & 0,226 & 0,634 & 1,797 \\
\cline { 2 - 5 } & Sanitasi Ruangan & 2,038 & 0,153 & 5,265 \\
\cline { 2 - 5 } & Sirkulasi Udara & 7,111 & 0,008 & 29,018 \\
\hline \multirow{2}{*}{4} & Sanitasi Ruangan & 2,475 & 0,116 & 5,976 \\
\cline { 2 - 5 } & Sirkulasi Udara & 8,113 & 0,004 & 33,773 \\
\hline & Sirkulasi Udara & 10,269 & 0,001 & 45,000 \\
\hline
\end{tabular}

Tabel 4 di atas menunjukkan bahwa setelah semua variabel bebas yang diprediksi memiliki hubungan dengan angka kuman udara digabungkan dalam sebuah model, ternyata hanya variabel sirkulasi udara yang memiliki hubungan positif yang signifikan dengan kualitas angka kuman udara pada ruang persalinan praktik bidan swasta di Kota Banjarbaru dengan nilai risiko relatif sebesar 45 kali. Secara teoritis hal ini dapat dikarenakan:

a. Udara bukan merupakan habitat untuk mikroorganisme, sel-sel mikroorganisme berada dalam udara sebagai kontaminan bersama debu dan percikan ludah atau air yang kemudian terbawa oleh hembusan angin ke udara (8).

b. Adanya aliran dan tekanan udara dari ventilasi mekanik dapat mendorong udara di dalam ruangan keluar ruangan dari celah-celah ventilasi dan di gantikan dengan udara yang telah tersaring melalui filter udara yang ada di dalam AC. c. Perbedaan suhu dan tekanan udara di dalam ruangan dan di luar ruangan menentukan arah aliran udara, dimana pada ruangan dengan suhu udara yang lebih rendah dari luar ruangan, maka aliran udara akan mengalir dari luar ruangan dengan suhu yang lebih tinggi ke dalam ruangan melalui lubang ventilasi dan dikeluarkan melalui jendela atau lubang pada sisi yang berlawanan, seperti celah pintu, karena suhu udara yang lebih tinggi mempunyai tekanan lebih besar. Sehingga akan mendorong udara di dalam ruangan yang mengandung mikroorganisme lebih banyak untuk di gantikan dengan udara luar yang kemungkinan kandungan mikroorganismenya lebih sedikit karena adanya radiasi sinar ultra violet dan panas matahari (9). 


\section{KESIMPULAN DAN SARAN Kesimpulan}

Sirkulasi udara ruang persalinan merupakan variabel yang berpengaruh secara signifikan dan memberikan kontribusi paling besar terhadap kualitas angka kuman udara pada ruang persalinan praktik bidan swasta di Kota Banjarbaru, hal ini dikarenakan udara bukanlah habitat bagi mikroba, sehingga keberadaanya di udara karena terbawa oleh hembusan angin bersama debu atau percikkan air. Hembusan angin atau aliran udara di dalam ruangan di pengaruhi oleh adanya sirkulasi udara berupa ventilasi ruangan.

\section{Saran}

1. Dinas Kesehatan agar lebih meningkatkan pengawasan, khususnya sanitasi pada tempat praktik bidan swasta.

2. Bidan pada praktik bidan swasta agar lebih memperhatikan kesehatan lingkungan dan sanitasi ruang persalinan.

\section{KEPUSTAKAAN}

1. Tietjen, L., Bossemeyer, D., McIntosh, N., (2004) Panduan Pencegahan Infeksi untuk Fasilitas Pelayanan Kesehatan dengan Sumber Daya Terbatas. Penerjemah S., Djajadilaga, Santoso, B.I., Yayasan Bina Pustaka Sarwono Prawiroharja bekerjasama dengan JNPKKR/POGI dan JHPIEGO (Program MNH \& STARH) Jakarta.

2. Kusnanto, H. (1997) Pengendalian Infeksi Nosokomial. Mitragama Widya, Yogyakarta.
3. Sanropie, D. Soemini, Marlina, N., Poerwanto, P., Wardoyo, Hernady,S., Prihatin, PE., Asmawidjaja, T., Sancoko, H., Sutena, M., Masra, F., Nerawati, ATD. (1989) Komponen Sanitasi Rumah Sakit Untuk Institusi Pendidikan Tenaga Sanitasi. Pusat Pendidikan Tenaga Kesehatan, Jakarta.

4. Departemen Kesehatan RI (2002) Keputusan Menteri Kesehatan RI No. 1335/MENKES/SK/X/2002 tentang Standar Operasional Pengambilan dan Pengukuran Sampel Kualitas Udara Ruangan Rumah Sakit. Dirjen PPM\&PL, Jakarta

5. Departemen Kesehatan RI (2004) Keputusan Menteri Kesehatan RI No.. 1204/MENKES/SK/X/2004 tentang Persyaratan kesehatan Lingkungan Rumah Sakit. Dirjen PPM\&PL, Jakarta

6. Volk, W.A., dan Wheeler, M.F., (1990) Mikrobiologi Dasar Jilid 2 . Editor Adisoemarto, S. Penerbit Erlangga, Jakarta.

7. Ibrahim, C.S. (1984) Perawatan Kebidanan Jilid II. Bharata Karya Aksara, Jakarta.

8. Muslimin dan Lucia, W.(1995) Mikrobiologi Lingkungan. Direktorat Jendral Pendidikan Tinggi dan Kebudayaan, Jakarta

9. Pujiastuti, L., Rendra, dan Santoso (1998) Kualitas Udara dalam Ruangan. Departemen Pendidikan dan Kebudayaan, Surabaya. 